\title{
Resenha: Família e Drogas: Prática e Teoria a Serviço da Prevenção
}

\author{
Eduardo Chaves da Silva ${ }^{1}$ \\ Fabrício Guimarães \\ Núcleo Psicossocial Forense \\ Universidade de Brasília
}

\section{Book Review: Family and Drug Abuse: Practice and Theory for Prevention Purposes}

O objetivo deste trabalho é discutir sobre a importância da obra "Drogas, pais e filhos" (Mussini, 2005), que ressalta o papel da família na prevenção ao uso indevido de drogas. A análise do livro baseia-se na experiência prática dos autores deste artigo no acompanhamento de casos de usuários de drogas ilícitas no contexto da Justiça do Distrito Federal.

A obra, composta por 17 capítulos, baseia-se na experiência profissional de 10 anos do autor que, diferentemente da maioria dos teóricos que escrevem sobre o tema, seguiu o caminho inverso, ou seja, a prática antecedeu a teoria. Ao lidar com casos de uso indevido de drogas em diversas faixas etárias, o autor pôde constatar que esse uso era uma forma que o usuário tinha para fugir de determinados problemas familiares, fazendo com que a droga fosse consumida sem uma reflexão de como se dava o uso e quais os danos que o usuário poderia sofrer.

A proposta de conscientização seria a de dar ao usuário e sua família os instrumentos para refletir sobre o uso de drogas. Esse argumento é corroborado por Sudbrack (2006), que assegura que

o trabalho de prevenção do uso de drogas evoluiu da repressão ao usuário e do amedrontamento da população para um novo enfoque, voltado para a educação e para a saúde, centrado na valorização da vida e na participação da comunidade (Sudbrack, 2006, p. 166).

Apresentar os motivos exatos que levam uma pessoa a usar drogas não é o objetivo principal de Mussini, no entanto o autor chama a atenção para a responsabilidade da família frente ao problema e as possibilidades de interferir positivamente na prevenção. A proposta é mostrar como devem ser feitos os contatos com esse usuário, a forma que os pais e educadores devem agir ao saber desse uso e, principalmente, a imposição de limites e estrutura (Mussini, 2005). Ao refletir sobre a função da família no que se refere ao uso de drogas, Mussini possibilita a abertura de novas perspectivas sobre o processo de amadurecimento das relações interfamiliares na estruturação de regras e valores para o usuário, pois através de um discurso mode-

1 Endereço: SRTVS Quadra 701, Bloco N, Lote 08, 4 andar, Brasília, DF, Brasil 70340-903.E-mail: edustradlin@gmail.com rado, consegue atingir de forma direta tanto os pais como os filhos. É através dessa linguagem que o autor mostra que a família, mais precisamente os pais, é a base de valores éticos e morais, e conseqüentemente, facilitadores de um processo de crescimento pessoal que leva o filho a refletir sobre seus atos e o melhor caminho seguir, consciente de suas escolhas.

Entretanto, nas últimas décadas, a família nuclear - ou reconstituída - toma o espaço da família originária tradicional - pai, mãe, filhos -, fazendo com que os contatos sejam restringidos aos membros da família externa, como amigos, tios, esposas etc, buscando os laços que vem se perdendo na família originária. Nesse sentido, Minuchin (1982) coloca a importância de se considerar essas mudanças na estrutura familiar tradicional ao se debater o assunto prevenção.

Ainda que mudanças sejam constantes na estrutura familiar brasileira, especialmente na última década, Silva (2006) argumenta que mesmo havendo mitos, valores e tabus a respeito de estruturas familiares que divergem do modelo originário tradicional, o uso indevido de drogas no âmbito familiar não se associa diretamente ao tipo de estrutura que a família apresenta. Dessa forma, depreende-se que o papel da família é mais importante no que diz respeito ao trato da questão no sentido de prevenção do que atribuir a relação de causa à determinada estrutura familiar.

Mussini (2005) defende a importância da manutenção de certos valores e condutas socialmente aceitáveis que os pais devem ter para com os filhos, a fim de prevenir o uso de drogas na família. Entretanto, relacionar a prevenção a certos valores torna esse processo mais lento, justamente pelo fato de a estrutura familiar no Brasil vir sofrendo diversas alterações em sua dinâmica: a mulher está cada vez mais no papel de provedora do lar que outrora era, nas camadas médias e altas da população, papel predominantemente masculino e as relações típicas da família patriarcal estão se transformando, não sendo um padrão de referência único de família para a sociedade atual brasileira.

Considerando-se a importância de explicitar as relações de gênero no debate sobre papéis familiares no tocante à prevenção ao uso de drogas, uma abordagem mais específica nesse sentido poderia ser mais trabalhada ao decorrer da obra, onde a análise se focou ora em figuras, ora em termologias masculinas. Por outro lado, mesmo em famílias patriarcais estruturadas, as figuras maternas são representativas e, muitas vezes, as responsáveis pela transmissão de valores e conceitos morais aos filhos, daí a importância 
de estruturar o debate considerando essas manifestações evidentes na atual família brasileira.

Dentro dessa perspectiva, não se deve isolar a variável família na análise e elaboração de qualquer projeto de prevenção, uma vez que outros fatores, como a mídia, escola, etc são ambientes que nem sempre a família pode intervir. Ao analisar a experiência prática de Mussini (2005), juntamente com sua obra, nota-se a forma estereotipada e naturalizada com que os jovens são tratados nas tentativas de informação e prevenção ao uso de drogas. Muitas vezes são colocados como meros espectadores do processo de prevenção, minando-lhes sua autonomia para tomar decisões, desconsiderando sua subjetividade.

$\mathrm{Na}$ experiência dos autores, é evidente que muitos jovens chegam à Justiça por falta de prevenção primária em relação ao uso indevido das drogas. Muitos relatam que se tivessem mais informações, não teriam tantos problemas com as drogas e, em conseqüência, com a Justiça. Dessa forma, a obra cumpre seu papel, pois fornece subsídios para a melhor difusão de práticas de prevenção ao uso de drogas com argumentos simples e diretos.

Com a vivência prática do tema, Mussini mostra um novo ângulo de análise e informação para pais e educadores, reportando a exemplos práticos sempre que necessário, levando o leitor a compreender as idéias básicas das várias propostas apresentadas, bem como a descobrir novos ca- minhos, a fim de viabilizar da melhor maneira possível o trabalho de prevenção ao uso indevido de drogas.

\section{Referências}

Minuchin, S. (1982). Famílias: Funcionamento e tratamento. Porto Alegre: Ed. Artes Médicas.

Mussini, M. (2005). Drogas, pais e filhos. Rio de Janeiro: Ed. Ciência Moderna Ltda.

Silva, E. C. (2006). Relações intrafamiliares no tocante à prevenção ao uso de drogas - um estudo exploratório a partir dos casos atendidos no NUPS. Em E.C.B. Roque, M.L.R. Moura \& I. Ghesti (Orgs.), Novos paradigmas na Justiça Criminal: Relatos de experiências do Núcleo Psicossocial Forense do TJDFT. Brasília: TJDFT.

Sudbrack, M. F. O. (2006). O trabalho comunitário e a construção de redes sociais. Em Secretaria Nacional Antidrogas (SENAD), Curso de prevenção do uso indevido de drogas para educadores de escolas públicas. Brasília: Editora UnB.
Recebido em 10.05.2007 Aceito em 09.07.2007 